\title{
PENGARUH SIKAP, MINAT, MOTIVASI, DAN GELAR AKUNTAN TERHADAP KEPUTUSAN MENEMPUH PENDIDIKAN PROFESI AKUNTANSI (PPAk) DI UNIVERSITAS MUHAMMADIYAH METRO
}

Oleh :

\section{Eti Yuniarti}

Email: eti-2002@gmail.com

Fakultas Ekonomi, Universitas Muhammadiyah Metro

\begin{abstract}
Accounting profession education is expected to answer the needs of the importance of human resources and competent professionals in the field of accounting. Keeping in following the requirements of the accounting profession education is SI Accounting undergraduate, or graduate D-IV Department of Accounting, hence the need for attitude, interest and motivation of students studying accounting to the accounting profession. With the attitudes, interests, and motivations, expected growth accounting student wishes to study the accounting profession, which in turn will give birth to a professional public accountants. Accounting student's decision to study the accounting profession, not in spite of various factors, both factors of student self (internal), as well as external factors (external). Internal factors among which is the attitude, interest, and motivation. While external factors, namely the title of accountant.

The purpose of this study is the first, provide empirical evidence influence attitudes toward education profeesi accounting decisions (PPAk), both provide empirical evidence Effect of interest to decision akuntasni professional education (PPAk), third provides empirical evidence motiasi influence on the decision akuntasni professional education ( PPAk), kempat provide empirical evidence of the effect of accounting degree to decision akuntasni professional education (PPAk).
\end{abstract}

Keywords: Attitudes, Interests, Motivation, Degree Accountant, Accounting Professional Education

\section{PENDAHULUAN}

Profesi mengandung arti suatu pekerjaan yang mensyaratkan pengetahuan, keahlian, dan dan profesionalitas yang dihasilkan melalui pendidikan. Dalam perspektif tersebut, Pendidikan Profesi Akuntansi (PPAk) dinilai penting bagi mahasiswa jurusan akuntansi yang ingin menekuni profesi sebagai akuntan.

Pendidikan profesional berkelanjutan bagi seorang akuntan merupakan sarana memelihara kompetensinya dalam menjalanan tugas profesionalnya. Profesi akuntan menuntut kemampuan yang selalu terpelihara dalam rangka mempertahankan kepercayaan masyarakat. (Gede: 2005, 49) 
Keberadaan pendidikan profesi akuntansi semakin penting dewasa ini, mengingat Indonesia mulai menerapkan International Financial Reporting Standard (IFRS) pada 2012. Namun, karena keterbatasan pendidikan, jumlah dan kompetensi akuntan Indonesia terbilang belum memadai.

Indarto dalam (IAI: 2009, 25) mencatat, total lulusan pendidikan profesi akuntansi dari penguruan tinggi negeri hanya 2.153. Pada tahun 2008 sedikitnya 162.205 mahasiswa akuntansi yang aktif. Namun, jumlah akuntan publik di Indonesia baru 887. Jumlah yang sangat tidak memadai jika dibanding populasi penduduk Indonesia yang mencapai 220 juta jiwa.

Kontribusi pendidikan profesi akuntansi juga dinilai masih kurang dalam melululuskan akuntan. Saat ini, misalnya, baru ada 36 perguruan tinggi (PT) yang mendapatkan rekomendasi menyelenggarakan program Pendidikan Profesi Akuntan (PPAk). Lambatnya pertumbuhan jumlah akuntan publik, lima sampai sepuluh tahun ke depan akan terjadi penurunan jumlah akuntan publik secara signifikan. Jika itu yang terjadi, yang akan masuk adalah akuntanakuntan publik asing, terutama dari negara-negara ASEAN setelah industri jasa ini diliberalisasi. (IAI: 2009, 25)

Pendidikan Profesi Akuntansi (PPAk) adalah jenjang pendidikan tambahan pada perguruan tinggi setelah progam sarjana ekonomi yang ditujukan bagi seorang lulusan sarjana ekonomi jurusan akuntansi yang ingin mendapatkan gelar Akuntan.

Berdasarkan Surat Keputusan (SK) Mendiknas No. 179/U/2001 menyatakan bahwa Pendidikan Profesi Akuntansi diselenggarakan di perguruan tinggi sesuai dengan persyaratan, tata cara dan kurikulum yang diatur oleh Ikatan Akuntan Indonesia (IAI), sehingga lulusan sarjana strata satu (S1) jurusan akuntansi berkesempatan untuk menempuh Pendidikan Profesi Akuntansi di perguruan tinggi yang telah ditunjuk oleh Direktorat Jenderal Pendidikan Tinggi. Setelah menempuh Pendidikan Profesi Akuntansi para lulusan sarjana strata satu (S1) berhak memperoleh gelar profesi Akuntan (Ak), sehingga akan semakin berpeluang untuk memilih karir sebagai auditor pemerintahan, auditor internal, akuntan sektor publik, akuntan manajemen, akuntan pendidik, akuntan perpajakan, maupun akuntan keuangan.

Lulusan Pendidikan Profesi Akuntansi diharapkan mempunyai daya saing yang lebih tinggi dalam liberalisasi jasa akuntan dewasa ini. Lulusan Pendidikan Profesi Akuntansi berhak mendapatkan Register Negara dan boleh mengikuti Ujian Sertifikasi Akuntan Publik (USAP). USAP merupakan persyaratan penting untuk mendapatkan ijin praktik sebagai Akuntan Publik.

Pendidikan profesi akuntansi diharapkan mampu menjawab kebutuhan akan pentingnya sumber daya manusia yang profesional dan kompeten di bidang Akuntansi. Mengigat persyaratan mengikuti pendidikan profesi akuntansi adalah sarjana S-I Akuntansi, atau lulusan D-IV Jurusan Akuntansi, maka perlu adanya persepsi positif dari mahasiswa akuntansi terhadap pendidikan profesi akuntansi. Dengan adanya persepsi positif tersebut, diharapkan tumbuhnya minat mahasiswa akuntansi untuk menempuh pendidikan profesi akuntansi, yang pada gilirannya akan melahirkan akuntan publik yang profesional. 


\section{Kerangka Pemikiran}

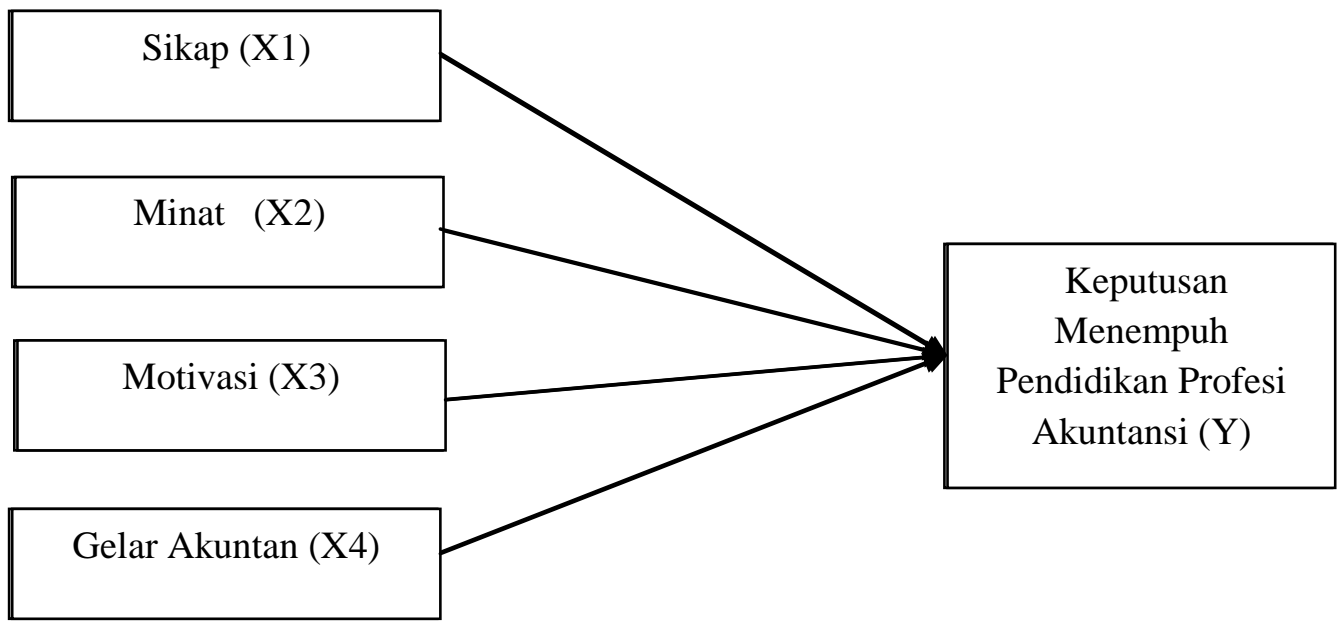

\section{Hipotesis Penelitian}

H1: Sikap berpengaruh signifikan terhadap keputusan menempuh pendidikan profesi akuntansi

H2: Minat berpengaruh signifikan terhadap keputusan menempuh pendidikan profesi akuntansi

H3: Motivasi berpengaruh signifikan terhadap keputusan menempuh pendidikan profesi akuntansi

H4: Gelar akuntan berpengaruh signifikan terhadap keputusan menempuh pendidikan profesi akuntansi

\section{METODE PENELITIAN}

Jenis penelitian yang digunakan dalam penelitian ini adalah analisis kuantitatif yaitu menjelaskan pengaruh antar variabel dengan menganalisis data numeric (angka) mengunakan data statistik melalui pengujian hipotesa. Objek penelitian dalam penelitian ini adalah variabel independen yang terdiri dari sikap, minat, motivasi, gelar akuntan, dan variabel dependen, yaitu keputusan menempuh pendidikan profesi akuntan (PPAk). Adapun lokasi penelitian adalah Universitas Muhammadiyah Metro. Penelitian ini dilaksanakan selama kurang lebih 1 (Minggu). Adapun populasi dalam penelitian ini adalah mahasiswa jurusan akuntansi Fakultas Ekonomi Universitas Muhammadiyah Metro. Teknik sampling yang digunakan dalam penelitian ini adalah teknik purposive sampling yaitu teknik penentuan sampel dengan pertimbangan tertentu. (Sugiyono: 2009, 55)

Pertimbangan yang digunakan adalah asumsi mahasiswa pada tingkat tersebut telah memperoleh semua mata kuliah akuntansi dan mungkin telah memiliki pandangan untuk menempuh pendidikan profesi akuntansi (PPAk). Berdasarkan pertimbangan tersebut, sampel yang dipilih adalah mahasiswa tingkat 
akhir atau mahasiswa angkatan tahun akademik 2011/2012 yang berjumlah 65 orang.

Teknik pengumpulan data dalam penelitian ini menggunakan penelitian pustaka (Library Research) dan penelitian lapangan (Field Research). Selanjutnya akan diolah dengan spss 17, dengan alat analisis: uji kualitas data (uji validitas dan reliabilitas), uji asumsi kliasik (uji normalitas, linearitas, dan multikolinieritas), uji hipotesis (uji koefesien determinasi $R^{2}$, uji statistik t, uji statistik f).

\section{HASIL DAN PEMBAHASAN}

Responden dalam penelitian ini adalah mahasiswa jurusan akuntansi semester VIII. Berikut adalah deskripsi mengenai identitas responden penelitian yang terdiri dari jenis kelamin :

Tabel. 1 Gambaran Umum Responden Berdasarkan Jenis Kelamin

\begin{tabular}{|l|c|c|}
\hline \multicolumn{1}{|c|}{ Jenis Kelamin } & Jumlah & Persentasi \\
\hline Perempuan & 30 & $75 \%$ \\
Laki-laki & 10 & $25 \%$ \\
\hline
\end{tabular}

\section{UJI VALIDITAS DATA}

Suatu instrumen dinyatakan valid apabila koefisien korelasi $r$ hitung lebih besar dibandingkan koefisien korelasi r-tabel pada taraf signifikansi 0,05. Hal ini dapat di lihat pada tabel di bawah, dimana r-tabel adalah 0,312 yang dihitung dari $\mathrm{N}-2=40-2=38$ (dimana $\mathrm{N}$ adalah jumlah data).

Tabel.2 Hasil Uji Validitas Data

\begin{tabular}{|l|c|l|l|c|}
\hline Instrumen Variabel & $\begin{array}{l}\text { Butir } \\
\text { Instrumen } \\
\text { Pertanyaan }\end{array}$ & $\begin{array}{l}\text { R } \\
\text { Hitung }\end{array}$ & $\begin{array}{l}\text { R } \\
\text { Tabel }\end{array}$ & Keterangan \\
\hline Sikap (X1) & K1 &, 632 & 0,312 & Valid \\
\hline & K2 &, 722 & 0,312 & Valid \\
\hline & K3 &, 750 & 0,312 & Valid \\
\hline & K4 &, 631 & 0,312 & Valid \\
\hline & K5 &, 695 & 0,312 & Valid \\
\hline & K6 &, 613 & 0,312 & Valid \\
\hline
\end{tabular}


ISSN Cetak : 1978-6579

ISSN Online : 2477-2984

\begin{tabular}{|c|c|c|c|c|}
\hline Instrumen Variabel & $\begin{array}{l}\text { Butir } \\
\text { Instrumen } \\
\text { / } \\
\text { Pertanyaan }\end{array}$ & $\begin{array}{l}\text { R } \\
\text { Hitung }\end{array}$ & $\begin{array}{l}\mathbf{R} \\
\text { Tabel }\end{array}$ & Keterangan \\
\hline & $\mathrm{K} 7$ & ,766 & 0,312 & Valid \\
\hline & K8 & ,596 & 0,312 & Valid \\
\hline & K9 & 698 & 0,312 & Valid \\
\hline & K10 & ,703 & 0,312 & Valid \\
\hline & K11 & ,588 & 0,312 & Valid \\
\hline & K12 & ,515 & 0,312 & Valid \\
\hline & K13 & ,766 & 0,312 & Valid \\
\hline & K14 & ,703 & 0,312 & Valid \\
\hline & K15 & ,474 & 0,312 & Valid \\
\hline Minat (X2) & K16 & ,507 & 0,312 & Valid \\
\hline & K17 & ,459 & 0,312 & Valid \\
\hline & K18 & ,482 & 0,312 & Valid \\
\hline & K19 & ,434 & 0,312 & Valid \\
\hline & K20 & ,416 & 0,312 & Valid \\
\hline & K21 & ,539 & 0,312 & Valid \\
\hline & K22 & ,444 & 0,312 & Valid \\
\hline & K23 & ,612 & 0,312 & Valid \\
\hline & K24 & ,471 & 0,312 & Valid \\
\hline & K25 & ,535 & 0,312 & Valid \\
\hline & K26 & ,540 & 0,312 & Valid \\
\hline & K27 & ,408 & 0,312 & Valid \\
\hline & K28 & ,536 & 0,312 & Valid \\
\hline & K29 & ,455 & 0,312 & Valid \\
\hline & K30 & 667 & 0,312 & Valid \\
\hline
\end{tabular}




\begin{tabular}{|c|c|c|c|c|}
\hline Instrumen Variabel & $\begin{array}{l}\text { Butir } \\
\text { Instrumen } \\
\text { / } \\
\text { Pertanyaan }\end{array}$ & $\begin{array}{l}\text { R } \\
\text { Hitung }\end{array}$ & $\begin{array}{l}\mathbf{R} \\
\text { Tabel }\end{array}$ & Keterangan \\
\hline \multirow[t]{15}{*}{ Motivasi (X3) } & K31 & ,476 & 0,312 & Valid \\
\hline & K32 & ,549 & 0,312 & Valid \\
\hline & K33 & ,508 & 0,312 & Valid \\
\hline & K34 & ,548 & 0,312 & Valid \\
\hline & K35 & 312 & 0,312 & Valid \\
\hline & K36 & 604 & 0,312 & Valid \\
\hline & K37 & ,533 & 0,312 & Valid \\
\hline & K38 & ,390 & 0,312 & Valid \\
\hline & K39 & ,518 & 0,312 & Valid \\
\hline & K40 & ,507 & 0,312 & Valid \\
\hline & K41 & 611 & 0,312 & Valid \\
\hline & K42 & ,554 & 0,312 & Valid \\
\hline & K43 & ,503 & 0,312 & Valid \\
\hline & K44 &, 566 & 0,312 & Valid \\
\hline & K45 & ,580 & 0,312 & Valid \\
\hline \multirow[t]{9}{*}{ Gelar Akuntan (X4) } & K46 & ,374 & 0,312 & Valid \\
\hline & K47 & ,630 & 0,312 & Valid \\
\hline & K48 & ,507 & 0,312 & Valid \\
\hline & K49 & ,552 & 0,312 & Valid \\
\hline & K50 & ,733 & 0,312 & Valid \\
\hline & K51 & 603 & 0,312 & Valid \\
\hline & K52 & ,548 & 0,312 & Valid \\
\hline & K53 & 491 & 0,312 & Valid \\
\hline & K54 & ,735 & 0,312 & Valid \\
\hline
\end{tabular}




\begin{tabular}{|c|c|c|c|c|}
\hline Instrumen Variabel & $\begin{array}{l}\text { Butir } \\
\text { Instrumen } \\
\text { / } \\
\text { Pertanyaan }\end{array}$ & $\begin{array}{l}\mathbf{R} \\
\text { Hitung }\end{array}$ & $\begin{array}{l}\text { R } \\
\text { Tabel }\end{array}$ & Keterangan \\
\hline & K55 & ,763 & 0,312 & Valid \\
\hline & K56 & ,616 & 0,312 & Valid \\
\hline & K57 & ,529 & 0,312 & Valid \\
\hline & K58 & ,374 & 0,312 & Valid \\
\hline & K59 & ,606 & 0,312 & Valid \\
\hline & K60 & ,684 & 0,312 & Valid \\
\hline \multirow[t]{15}{*}{ PPAK (Y) } & K61 & ,410 & 0,312 & Valid \\
\hline & K62 & ,443 & 0,312 & Valid \\
\hline & K63 & ,572 & 0,312 & Valid \\
\hline & K64 & ,492 & 0,312 & Valid \\
\hline & K65 & ,636 & 0,312 & Valid \\
\hline & K66 & ,494 & 0,312 & Valid \\
\hline & K67 & ,393 & 0,312 & Valid \\
\hline & K68 & ,502 & 0,312 & Valid \\
\hline & K69 & ,590 & 0,312 & Valid \\
\hline & K70 & ,368 & 0,312 & Valid \\
\hline & K71 & ,572 & 0,312 & Valid \\
\hline & K72 & ,572 & 0,312 & Valid \\
\hline & K73 & ,471 & 0,312 & Valid \\
\hline & K74 &, 557 & 0,312 & Valid \\
\hline & K75 & ,427 & 0,312 & Valid \\
\hline
\end{tabular}

\section{UJI RELIABILITAS DATA}

Uji reabilitas data dilakukan dengan menggunakan metode Cronbach's Alpha dimana suatu instrumen dikatakan reliabel bila memiliki koefisien 
keandalan reliabilitas sebesar 0,60 atau lebih. Hasil pengujian reliabilitas data dapat dilihat pada tabel berikut:

Tabel. 3 Hasil Uji Reliabilitas

\begin{tabular}{|l|c|c|c|}
\hline \multicolumn{1}{|c|}{ Variabel } & $\begin{array}{c}\text { Koefisien } \\
\text { Cronbach's } \\
\text { Alpha }\end{array}$ & $\begin{array}{c}\text { Batas } \\
\text { Reliabilita } \\
\text { s }\end{array}$ & $\begin{array}{c}\text { Keteranga } \\
\text { n }\end{array}$ \\
\hline Sikap (X1) & .786 & 0,6 & Reliabel \\
Minat (X2) & .740 & 0,6 & Reliabel \\
Motivasi (X3) & .743 & 0,6 & Reliabel \\
Gelar Akuntan (X4) & .753 & 0,6 & Reliabel \\
Pendidikan Profesi Akuntansi & .747 & 0,6 & Reliabel \\
(Y) & & & \\
\hline
\end{tabular}

Berdasarkan tabel hasil uji reliabilitas data di atas, menunjukkan bahwa setiap item memiliki koefisien alpha lebih besar dari 0,60 sehingga seluruh item dinyatakan reliabel dan dapat digunakan untuk pengujian selanjutnya.

\section{UJI NORMALITAS}

Pengujian normalitas data dilakukan untuk memenuhi persyaratan model regresi bahwa data yang diperoleh memiliki sifat normal. Dalam pengujian ini, suatu data dikatakan berdistribusi normal jika sebaran data yang ada menyebar merata ke semua daerah kurva normal yang ditunjukkan pada hasil Histogram dan Normal Probability Plot.

Hasil Uji Normalitas dan Normal P-Plot Hasil Uji Normalitas dan Normal P-

Plot

Normal P-P Plot of Regression Standardized Residual

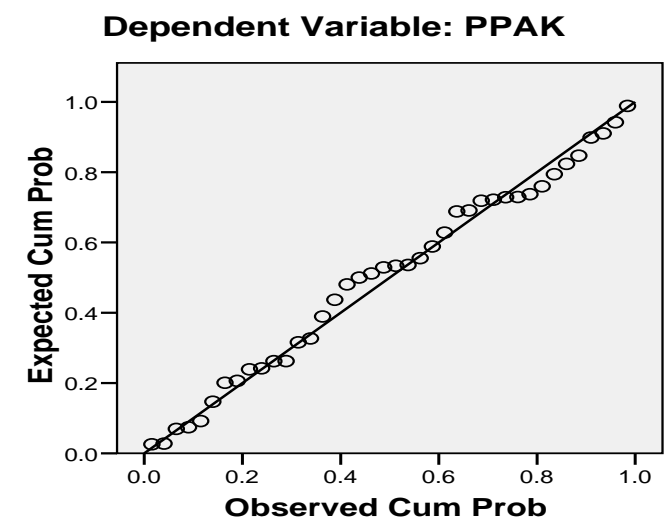




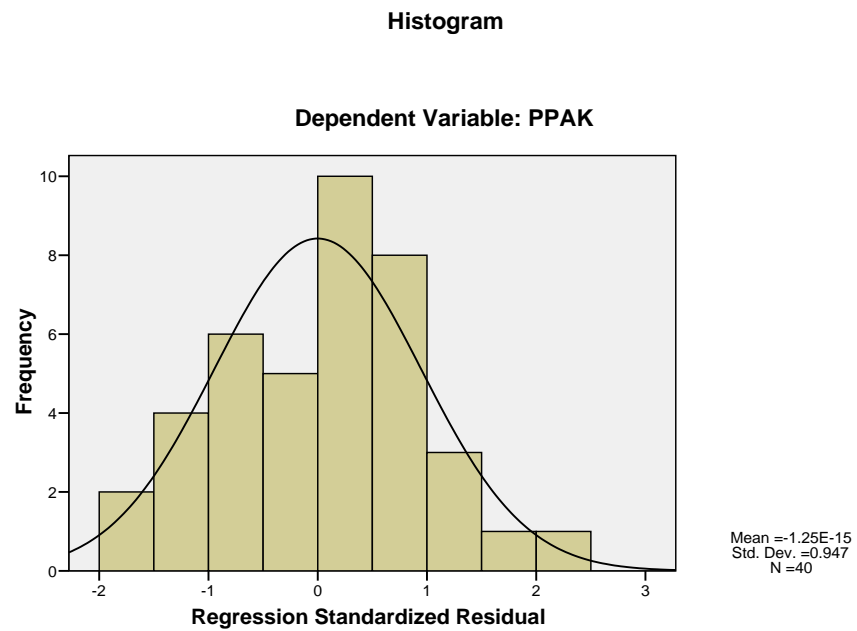

Berdasarkan gambar di atas, terlihat bahwa kurva histogram membentuk seperti gunung atau lonceng sehingga dapat dikatakan bahwa data terdistribusi dengan normal. Demikian halnya dengan grafik Normal Probability Plot di atas, dapat di lihat data menyebar disekitar garis diagonal dan mengikuti arah garis diagonal, oleh karena itu model regresi memenuhi asumsi normalitas.

\section{HASIL UJI LINERITAS}

Uji linearitas bertujuan untuk mengetahui apakah variabel-variabel yang diteliti mempunyai hubungan yang linear atau tidak secara signifikan. Uji ini digunakan sebagai prasyarat dalam analisis korelasi atau regresi linear. Dasar pengambilan keputusan dalam uji linearitas jika nilai probabilitas $>0,05$ maka Hipotesis diterima,dan jika nilai probabilitas $<0,05$ maka Hipotesis ditolak.

Tabel 4. Hasil Uji Linearitas

\begin{tabular}{|l|c|c|}
\hline \multicolumn{1}{|c|}{ Variabel } & Sig. & Keterangan \\
\hline Sikap dengan Pendidikan Profesi Akuntansi & 0,936 & Linear \\
$\begin{array}{l}\text { Minat dengan Pendidikan Profesi Akuntansi } \\
\text { Motivasi dengan Pendidikan Profesi }\end{array}$ & 0,228 & Linear \\
$\begin{array}{l}\text { Akuntansi } \\
\text { GelarAkuntan dengan Pendidikan Profesi } \\
\text { Akuntansi (PPAk) }\end{array}$ & 0,963 & Linear \\
\hline
\end{tabular}




\section{HASIL UJI MULTIKOLONIARITAS}

Uji multikolinearitas bertujuan untuk menguji korelasi antara variabel bebas (independen) dalam regresi.

Tabel. 5 Hasil Pengujian Multikolinearitas

\begin{tabular}{|ll|l|l|l|}
\hline $\begin{array}{l}\text { Mod } \\
\text { el }\end{array}$ & \multicolumn{2}{|l|}{ Collinearity Statistics } & Keterangan \\
\hline & & Tolerance & VIF & \\
\hline 1 & $\begin{array}{l}\text { (Constant) } \\
\text { SIKAP }\end{array}$ &, 451 & 2,218 & Bebas Multikolinearitas \\
& $\begin{array}{l}\text { MINAT } \\
\text { MOTIVASI }\end{array}$ &, 915 & 1,093 & Bebas Multikolinearitas \\
& $\begin{array}{l}\text { GELAR } \\
\text { AKUNTAN }\end{array}$ &, 837 & 1,194 & Bebas Multikolinearitas \\
& & & & \\
\hline
\end{tabular}

\section{UJI KOEFISIEN DETERMINASI $\left(\mathbf{R}^{2}\right)$}

Koefisien determinasi (R2) merujuk kepada kemampuan dari variabel independen $(\mathrm{X})$ dalam menerangkan variabel dependen $(\mathrm{Y})$. Nilai R koefisien determinasi berkisar di antara nol sampai dengan satu. Komponen-komponen yang terkait dengan koefisien determinasi dapat dilihat pada tabel model summary di bawah ini:

Tabel. 6 Model Summary ${ }^{b}$

\begin{tabular}{|c|c|c|c|c|}
\hline Model & $\mathrm{R}$ & R Square & $\begin{array}{ll}\text { Adjusted } & \mathrm{R} \\
\text { Square } & \end{array}$ & $\begin{array}{l}\text { Std. Error of the } \\
\text { Estimate }\end{array}$ \\
\hline 1 & 917 & ,841 &, 823 & 1,987 \\
\hline
\end{tabular}

a Predictors: (Constant), Gelar Akuntan, Minat, Motivasi, Sikap

Berrdasarkan tabel di atas dapat diterangkan bahwa korelasi antara pengaruh sikap (X1), minat (X2), motivasi (X3), dan gelar akuntan (X4) terhadap keputusan menempuh pendidikan profesi akuntansi (Y) adalah 0,917. Selain itu, dapat diketahui besarnya pengaruh sikap (X1), minat (X2), motivasi (X3), dan gelar akuntan (X4), terhadap keputusan menempuh pendidikan profesi akuntansi (Y) melalui koefisien derterminasi, yaitu sebesar R2 x 100\% $=(0,917) 2 \times 100 \%=0$. $841 \times 100 \%=84,1 \%$. Sedangkan besarnya pengaruh variabel selain sikap (X1), minat (X2), motivasi (X3), dan gelar akuntan (X4), terhadap keputusan menempuh PPAk (Y) adalah sebesar $100 \%-84,1 \%=15,9 \%$. 


\section{UJI PARSIAL (UJI T)}

Kriteria pengujian yang digunakan adalah dengan membandingkan t-hitung dengan t-tabel berdasarkan tingkat signifikansi 0,05 dan 2 sisi dengan derajat kebebasan df (nk-1) = 40-4-1 = 35 (n adalah jumlah data dan $\mathrm{k}$ adalah jumlah variabel independen), sehingga t-tabel yang diperoleh dari tabel statistik adalah sebesar 2,030. Apabila t-hitung $\leq \mathrm{t}$-tabel maka hipotesis diterima, sedangkan apabila t-hitung >t-tabel maka Hipotesis ditolak.

Tabel. 7 Hasil uji Regresi Linear Berganda

\begin{tabular}{|c|c|c|c|c|c|c|}
\hline \multicolumn{7}{|c|}{ Coefficients $^{a}$} \\
\hline \multirow{2}{*}{\multicolumn{2}{|c|}{ Model }} & \multicolumn{2}{|c|}{$\begin{array}{c}\text { Unstandardized } \\
\text { Coefficients }\end{array}$} & \multirow{2}{*}{$\begin{array}{c}\text { Standardized } \\
\text { Coefficients } \\
\text { Beta }\end{array}$} & \multirow[t]{2}{*}{$\mathrm{t}$} & \multirow[t]{2}{*}{ Sig. } \\
\hline & & B & Std. Error & & & \\
\hline \multirow[t]{5}{*}{1} & (Constant) & 4,687 & 4,730 & & 0,991 & 0,329 \\
\hline & Sikap & 0,372 & 0,162 & 0,332 & 2,293 & 0,028 \\
\hline & Minat & 0,388 & 0,141 & 0,402 & 2,759 & 0,009 \\
\hline & Motivasi & 0,328 & 0,144 & $-0,096$ & 2,281 & 0,029 \\
\hline & Gelar Akuntan & $-0,095$ & 0,184 & 0,340 & $-0,517$ & 0,608 \\
\hline
\end{tabular}

a. Dependent Variable: Keputusan Menempuh PPAk

Sumber: Data primer yang diolah

Berdasarkan hasil t-hitung pada tabel di atas, maka dapat dijelaskan pengaruh masing-masing variabel independen terhadap variabel dependen sebagai berikut:

1. Variabel Sikap (X1) memiliki nilai t-hitung lebih besar dari nilai t-tabel $(2,293>2,030)$ dan nilai 'Sig.' lebih kecil dari taraf signifikansi yang digunakan $0,05(0,028<0,05)$. Hal ini menunjukkan bahwa sikap berpengaruh signifikan terhadap pendidikan profesi akuntansi atau dengan kata lain, hipotesis (H1) diterima.

2. Variabel Minat (X2) memiliki nilai t-hitung lebih besar dari nilai t-tabel $(2,759>2,030)$ dan taraf signifikansi yang lebih kecil dari $0,05(0,009<0,05)$. Hal ini menunjukkan bahwa variabel minat secara parsial berpengaruh signifikan terhadap keputusan menempuh pendidikan profesi akuntansi atau dengan kata lain, hipotesis (H2) diterima.

3. Variabel Motivasi (X3) memiliki nilai t-hitung lebih besar dari nilai t-tabel $(2,281>2,032)$ dan taraf signifikansi yang lebih kecil dari $0,05(0,029<0,05)$. Hal ini menunjukkan bahwa variabel motivasi secara parsial berpengaruh signifikan terhadap keputusan menempuh pendidikan profesi akuntansi atau dengan kata lain, hipotesis (H3) diterima.

4. Variabel Gelar Akuntan (X4) memiliki nilai t-hitung lebih kecil dari nilai ttabel $(0,517<2,030)$ dan taraf signifikansi yang lebih besar dari 0,05 $(0,62>0,05)$. Hal ini menunjukkan bahwa variabel gelar akuntan secara parsial 
tidak berpengaruh signifikan terhadap keputusan menempuh pendidikan profesi akuntansi atau dengan kata lain, hipotesis (H4) ditolak.

\section{HASIL UJI SIMULTAN (UJI F)}

Kriteria pengujiannya adalah dengan membandingkan F-hitung dengan Ftabel yang dapat diketahui dengan menghitung df1 (jumlah total variabel-1) $=5-1$ $=4$, dan df $2(\mathrm{n}-\mathrm{k}-1)=40-4-1=35$ (n adalah jumlah data dan $\mathrm{k}$ adalah jumlah variabel independen), sehingga F-tabel yang diperoleh dari tabel statistik adalah sebesar 2,64. Apabila F-hitung $\geq$ F-tabel maka Hipotesis diterima, dan apabila Fhitung $<$ F-tabel, maka Hipotesis ditolak.

Tabel. 8 Hasil Uji Simultan ANOVA(b)

\begin{tabular}{|ll|l|l|l|l|l|}
\hline $\begin{array}{l}\text { Mode } \\
1\end{array}$ & $\begin{array}{l}\text { Sum of } \\
\text { Squares }\end{array}$ & df & $\begin{array}{l}\text { Mean } \\
\text { Square }\end{array}$ & F & Sig. \\
\hline 1 & Regressio & 731,571 & 4 & 182,893 & 46,318 & 0,000 \\
& $\begin{array}{l}\text { Residual } \\
\text { Total }\end{array}$ & 138,204 & 35 & 3,949 & & \\
& 869,775 & 39 & & & \\
\hline
\end{tabular}

a Predictors: (Constant) Gelar Akuntan, Minat, Motivasi, Sikap

b Dependent Variable: Keputusan Menempuh PPAk

Berdasarkan hasil uji $\mathrm{F}$ pada tabel di atas, diperoleh nilai F-hitung sebesar 46,318 dengan nilai signifikansi sebesar $0,000(0,000<0,05)$, sedangkan F-tabel pada tingkat kepercayaan $95 \%(\alpha=0,05)$ adalah sebesar 2,64 . Hal ini berarti Fhitung > F-tabel $(46,318>2,64)$. Perhitungan tersebut menunjukkan bahwa variabel sikap, minat, motivasi, dan gelar akuntan, secara bersama-sama memiliki pengaruh signifikan pendidikan profesi akuntansi atau dengan kata lain, hipotesis diterima

\section{PEMBAHASAN}

\section{Pengaruh Sikap terhadap Keputusan Menempuh Pendidikan Profesi Akuntansi (PPAK)}

Berdasarkan hasil uji hipotesis Variabel Sikap (X1) memiliki nilai t-hitung lebih besar dari nilai t-tabel $(2,293>2,030)$ dan taraf signifikansi yang lebih kecil dari $0,05(0,028<0,05)$. Hal ini menunjukkan bahwa variabel sikap secara parsial berpengaruh signifikan terhadap keputusan mahasiswa untuk menempuh pendidikan profesi akuntansi atau dengan kata lain, hipotesis (H1) diterima.

Mahasiswa akuntansi yang akan menempuh pendidikan profesi akuntansi harus memiliki sikap yang positif yang menunjukan atau memperlihatkan menerima, mengakui, menyetujui, karena sikap diperhitungkan sebagai faktor yang mempengaruhi keputusan menempuh pendidikan profesi akuntansi (PPAk).

Sikap dikategorikan sebagai faktor dari dalam (indogen) yang mempengaruhi keputusan yang dapat berwujud perasaan mendukung atau memihak (favorable) dan perasaan tidak mendukung atau tidak memihak (unfavorable). 
Menurut Wirawan (1996:94) sikap diartikan sebagai "kesiapan pada seseorang untuk bertindak secara tertentu terhadap hal-hal tertentu" Menurut zimbardo dan Ebbesen dalam Ahmadi, (2012: 150) "sikap adalah suatu predisposisi atau keadaan mudah terpengaruh terhadap seseorang atau objek yang berisi komponenkomponen kognitif, afektif, dan behavior.

Dapat disimpulkan hasil penelitian ini bahwa variabel sikap menjadi faktor yang mempengaruhi mahasiswa dalam menempuh pendidikan profesi akuntansi. Hasil pengujian hipotesis menunjukkan hipotesis yang diajukan dalam penelitian diterima.

\section{Pengaruh Minat terhadap Keputusan Menempuh Pendidikan Profesi Akuntansi (PPAK)}

Berdasarkan hasil uji hipotesis Variabel Minat (X2) memiliki nilai t-hitung lebih besar dari nilai t-tabel $(2,759>2,032)$ dan taraf signifikansi yang lebih kecil dari $0,05(0,01<0,05)$. Hal ini menunjukkan bahwa variabel minat secara parsial berpengaruh signifikan terhadap keputusan menempuh pendidikan profesi akuntansi (PPAk) atau dengan kata lain, hipotesis (H2) diterima.

Minat berpengaruh signifikan terhadap pendidikan profesi akuntansi (PPAk) pada mahasiswa S-1 Akuntansi. Mahasiswa yang akan menempuh pendidikan profesi akuntansi harus memiliki minat yang positif, ketertarikan atau keinginan yang besar terhadap pendidikan profesi akuntansi .

Minat berperan penting dalam sebagai pendorong keputusan individu. Individu yang berminat terhadap suatu objek, akan berusaha memahami objek tersebut, dan berusaha sekuat tenaga untuk memperolehnya. Rebert dalam Muhibbin (2011:152) mengemukakan bahwa minat mempunyai ketergantungan pada faktor internal seperti perhatian, kemauan dan kebutuhan. Menurut Stotland dalam Walgito (2004:206) makin tinggi seseorang mempersepsi probabilitas tercapainya tujuan, dan makin besar pentingnya sesuatu tujuan, makin besar perasaan positif, atau perasaan senang yang ada dalam diri orang yang bersangkutan.

Dapat disimpulkan hasil penelitian ini minat berpengaruh terhadap pendidikan profesi akuntansi, mahasiswa S-1 akuntansi memiliki minat yang positif, keinginan yang besar atau ketertarikan terhadap pendidikan profesi akuntansi (PPAk). Semakin tinggi minat yang dimiliki mahasiswa, semakin tinggi pula keinginan mahasiswa akuntansi untuk menempuh pendidikan profesi akuntansi.

\section{Pengaruh Motivasi terhadap Keputusan Menempuh Pendidikan Profesi Akuntansi (PPAK)}

Berdasarkan hasil uji hipotesis Variabel Motivasi (X3) memiliki nilai thitung lebih besar dari nilai t-tabel $(2,281>2,032)$ dan taraf signifikansi yang lebih kcil dari $0,05(0,03<0,05)$. Hal ini menunjukkan bahwa variabel motivasi secara parsial berpengaruh signifikan terhadap pendidikan profesi akuntansi atau dengan kata lain, hipotesis (H3) diterima.

Hasil penguian hipotesis di atas sejalan dengan penelitian yang dilakukan oleh Perkasa (2010), Ikbal (2011), dan Wahyuni (2011) yang menjelaskan 
bahwa motivasi berpengaruh terhadap minat mahasiswa menempuh pendidikan profesi akuntansi (PPAk). Dalam ketiga penelitian di atas, motivasi karir, motivasi ekonomi, dan motivasi kualitas berpengaruh terhadap keputusan mahasiswa akuntansi dalam menempuh pendidikan profesi akuntansi (PPAk).

Mahasiswa yang akan menempuh pendidikan profesi akuntansi harus memiliki motivasi yang positif, ketertarikan atau keinginan yang besar terhadap pendidikan profesi akuntansi, motivasi untuk berprestasi dan menaktualisasikan diri karena motivasi atau dorongan muncul sebagai kekuatan untuk tercapainya tujuan.

Motivasi dapat terwujud di antaranya karena dorongan untuk berprestasi dan mengaktualisasikan diri yang ditandai oleh kebutuhan untuk meningkatkan performance (kinerja) dengan kesediaan menghadapi tugas dan tantangan yang sulit.

Menurut (Asrori:2008, 183) motivasi dapat diartikan "dorongan yang timbul pada diri seseorang, secara disadari atau tidak untuk melakukan suatu tindakan dengan tujuan tertentu." Dalam lain disebutkan "motivasi merupakan keadaan dalam diri individu atau organisme yang mendorong perilaku ke arah tujuan. (Walgito: 2004, 220)

Dapat disimpulkan hasil penelitian ini bahwa motivasi menjadi faktor yang mempengaruhi mahasiswa terhadap pendidikan profesi akuntansi. Penelitian ini sejalan dengan penelitian yang dilakukan oleh Perkasa, Ikbal (2011) bahwa variabel motivasi berpengaruh signifikan atau positif terhadap keputusan menempuh pendidikan profesi akuntansi. Dengan demikian semakin tinggi motivasi, maka ketertarikan mahasiswa S-1 akuntansi untuk mengikuti pendidikan profesi akuntansi pun semakin tinggi.

\section{Pengaruh Gelar Akuntan terhadap Keputusan Menempuh Pendidikan Profesi Akuntansi (PPAK)}

Berdasarkan hasil uji hipotesis variabel Gelar Akuntan (X4) memiliki nilai t-hitung lebih kecil dari nilai t-tabel $(0,517>2,030)$ dan taraf signifikansi yang lebih besar dari 0,05 $(0,62>0,05)$. Hal ini menunjukkan bahwa variabel gelar akuntan secara parsial tidak berpengaruh signifikan terhadap pendidikan profesi akuntansi atau dengan kata lain, hipotesis (H4) ditolak.

Gelar akuntan kurang berpengaruh terhadap keputusan mahasiswa menempuh pendidikan profesi akuntansi (PPAk), karena kurangnya pengetahuan mahasiswa terhadap potensi karir setelah memperoleh gelar akuntan. Mahasiswa juga beranggapan bahwa dengan memperoleh gelar akuntan, belum tentu langsung mendapatkan pekerjaan. Selain itu, mahasiswa berpandangan bahwa profesi akuntan merupakan profesi yang menuntut tanggung jawab besar kepada klien, dan publik, sehingga mendorong keraguan mahasiswa menempuh pendidikan profesi akuntansi. Akuntan adalah sebutan dan gelar profesional yang diberikan kepada seorang sarjana yang telah menempuh pendidikan di fakultas ekonomi jurusan akuntansi pada suatu universitas atau perguruan tinggi dan telah lulus Pendidikan Profesi Akuntansi (PPAk). Ketentuan mengenai praktik Akuntan di Indonesia diatur dengan Undang-Undang Nomor 34 Tahun 1954 tentang Pemakaian Gelar Akuntan 
(Accountant) yang mensyaratkan bahwa gelar akuntan hanya dapat dipakai oleh mereka yang telah menyelesaikan pendidikannya dari perguruan tinggi dan telah terdaftar pada Departemen Keuangan Republik Indonesia.

Berdasarkan Keputusan Menteri Pendidikan Nasional Nomor 179/u/2001 di atas, maka lulusan sarjana ekonomi jurusan akuntansi tidak langsung memperoleh gelar akuntan. Untuk dapat memperoleh gelar akuntan, maka mahasiswa tersebut harus mengikuti Pendidikan Profesi Akuntansi (PPAk) di perguruan tinggi yang bekerja sama dengan Ikatan Akuntan Indonesia (IAI). Dapat disimpulkan dari hasil penelitian ini bahwa gelar akuntan kurang berpengaruh terhadap keputusan mahasiswa menempuh pendidikan profesi akuntansi.

\section{SIMPULAN DAN SARAN}

Berdasarkan hasil penelitian, dapat diambil kesimpulan sebagai berikut:

1. Sikap dikategorikan sebagai faktor dari dalam (indogen) yang mempengaruhi keputusan yang dapat berwujud perasaan mendukung atau memihak (favorable) dan perasaan tidak mendukung atau tidak memihak (unfavorable). Dari hasil uji hipotesis menunjukan bahwa variabel sikap berpengaruh signifikan terhadap keputusan mahasiswa akuntansi Universitas Muhammadiya Metro untuk menempuh Pendidikan Profesi Akuntansi (PPAk).

2. Minat (interes) berarti kecenderungan dan kegairahan yang tinggi atau keinginan yang besar terhadap sesuatu. Minat berperan penting sebagai pendorong keputusan mahasiswa menempuh penddiikan profesi akuntansi. Dari hasil uji hipotesis menunjukkan bahwa variabel minat secara parsial berpengaruh signifikan terhadap keputusan mahasiswa akuntansi Universitas Muhammadiya Metro untuk menempuh Pendidikan Profesi Akuntansi (PPAk).

3. Motivasi dapat terwujud karena dorongan untuk berprestasi dan mengaktualisasikan diri yang ditandai oleh kebutuhan untuk meningkatkan performance (kinerja) dengan kesediaan menghadapi tugas dan tantangan yang sulit. Dari hasil uji hipotesis menunjukkan bahwa variabel motivasi secara parsial berpengaruh signifikan terhadap keputusan mahasiswa akuntansi Universitas Muhammadiya Metro untuk menempuh Pendidikan Profesi Akuntansi (PPAk).

4. Gelar akuntan kurang berpengaruh terhadap keputusan mahasiswa menempuh pendidikan profesi akuntansi, karena kurangnya pengetahuan mahasiswa terhadap potensi karir setelah memperoleh gelar akuntan. Berdasarkan hasil uji hipotesis menunjukkan bahwa variabel gelar akuntan secara parsial tidak berpengaruh signifikan keputusan mahasiswa akuntansi Universitas Muhammadiya Metro untuk menempuh Pendidikan Profesi Akuntansi (PPAk). Berdasarkan kesimpulan diatas, saran yang diharapkan menjadi masukan yang berguna bagi pihak-pihak yang berkepentingan yaitu sebagai berikut:

\section{Lembaga Pendidikan (Fakultas Ekonomi)}

Meskipun sikap, minat, dan motivasi memiliki pengaruh terhadap keputusan menempuh pendidikan profesi akuntansi, hendaknya perlu ditingkatkan kembali 
menjadi sangat tinggi, seperti dengan melakukan evaluasi terhadap mahasiswa, guna mengetahui seberapa besar wawasan mereka mengenai pendidikan profesi akuntansi itu sendiri.

2. Bagi peneliti selanjutnya

Disarankan kepada peneliti selanjutnya untuk dapat menambah atau mengembangkan variabel-variabel yang mendukung mahasiswa S-1 Akuntansi dalam menempuh pendidikan profesi akuntansi dan dikarenakan penelitian ini dilakukan hanya untuk mahasiswa tingkat akhir pada Jurusan Akuntansi Fakultas Ekonomi Universitas Muhammadiyah Metro saja, maka peneliti menyarankan penelitian dilakukan pada mahasiswa tingkat awal maupun menengah, serta dapat dilakukan penelitian di seluruh Universitas yang memiliki Program Studi Akuntansi khususnya di Metro dan Lampung atau pun diseluruh Indonesia.

\section{DAFTAR PUSTAKA}

Adi, Rianto.(2001). Metodoogi Penelitian Sosial dan Hukum. Jakarta: Granit.

Arikunto, Suharsimi. 2006. Prosedur Penelitian Suatu Pendekatan Praktik. Edisi Revisi VI. Jakarta: PT. Rineka Cipta

Bungin, Burhan.(2001). Metodologi Penelitian Sosial. Surabaya: Airlangga University Press.

Ghozali, Imam. (2006). "Aplikasi Analisis Multivariat Dengan Program SPSS". Badan Penerbit Universitas Dipenogoro. Semarang.

Gunarsa, (2004). Psikologi Prakatis Anak dan Remaja, Jakarta: Gunung Mulia

Harahap, Sofyan Syafri, (2012). Teori Akuntansi, Jakarta: Raja Grafindo Persada.

Hasibuan, Malayu, SP.(2003). Organisasi dan Motivasi. Jakarta: Bumi Aksara.

Hermawan, Asep.(2005). Penelitian Bisnis Paradigma Kuantitatif. Jakarta: Grasindo .

Ikatan Akuntan Indonesia (IAI) Edisi No. 17/Tahun III/Juni: 2009 (IAI: http://www.iaiglobal.or.id. diakses 7 Desember 2014)

Keputusan Menteri Pendidikan Nasional Republik Indonesia No. 179/u/2001 tentang Penyelenggaraan Pendidikan Profesi Akuntansi

Mangkuprawira, Sjafrie.(2011). Manajemen Sumber Daya Manusia Strategik. Jakarta: Ghalia Indonesia.

Muhibbin, (2011). Psikologi Belajar, Jakarta: Raja Grafindo Persada. 
Peraturan Menteri Keuangan No. 25/PMK/01/2014 tentang Akuntan Beregister Negara.

Robbins dan Judge.2008. Perilaku Organisasi, Alih Bahasa: Diana Angelica dkk. Jakarta: Salemba Empat.

Sapuri. (2009), Psikologi Islam, Jakarta: Kencana

Sirait, Justine, T.(2011). Memahami Aspek-aspek Pengelolaan Sumber Daya Manusia. Jakarta: Grasindo.

Sobur, Alex.(2003). Psikologi Umum. Bandung: Pustaka Setia.

Sudijono, Anas.(2012). Pengantar Statistik Pendidikan. Jakarta: Raja Grafindo Persada.

Sugiharto.(2000). Metode Statitistik untuk Bisnis dan Ekonomi. Jakarta: Gramedia

Sugiyono. 2008. Metode penelitian pendidikan pendekatan kuantitatif, kualitatif,dan $R \& D$. Bandung: Alfabeta.

Undang-undang No.34 Tahun 1954 tentang Pemakaian Gelar Akuntan

Walgito, Bimo.(2004). Pengantar Psikologi Umum. Yogyakarta : Andi Offset.

Wirawan Sarwono, (1996) Pengantar Umum Psikologi, Jakarta: Bulan Bintang

\section{Skripsi dan Jurnal}

Indra Rahardian, 2008. Pengaruh Motivasi terhadap Minat Mahasiswa untuk mengikuti Pendidikan Profesi Akuntansi (PPAk). Perguruan Tinggi yang terakreditasi dengan nilai A di Semarang. Skripsi

Perkasa, Yudhistira Bayu (2010). Pengaruh Motivasi Terhadap Minat Mahasiswa Untuk Mengikuti Pendidikan Profesi Akuntansi (PPAK). Jurusan Akuntansi, Fakultas Ekonomi, Universitas Brawijaya.

Wahyuni. (2011), Pengaruh Motivasi terhadap minat mahasiswa akuntansi untuk mengikuti pendidikan profesi Akuntansi (PPAk) (Studi Empiris Pada Perguruan Tinggi di Pekanbaru)

Tengker,Victor S. G. (2007). Pengaruh motivasi karir terhadap minat mahasiswa akuntansi untuk mengikuti pendidikan profesi akuntansi (PPAk) (Studi Pada Jurusan Akuntansi FE Unsrat Manado) 